\title{
Technological Change in the Workplace: A Statewide Survey of Community College Library and Learning Resources Personnel
}

\section{Carolyn E. Poole and Emmett Denny}

It is a commonly held belief that technostress caused by change is affecting library personnel, although research on its impact in two-year colleges is practically nonexistent. This investigation examined how employees in Florida community college library and learning resource centers are dealing with technological change in their work environment. The results of the investigation indicated that staff are reacting positively. However, greater attention needs to be directed toward improving their inclusion in decision-making, revising job descriptions, and experimenting with alternative reward systems.

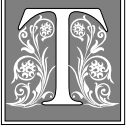

he professional library literature of the past decade is replete with articles on the rapidity of change taking place in libraries and its symptomatic technostress exhibited by library employees. Most studies have focused on technological challenges faced by MLS-degreed librarians in university work environments. Few, if any, researchers have paid comparable attention to staff in two-year community college libraries or in learning resource centers.

As the youngest stratum of the American higher education system, community colleges tend to be more flexible, innovative, and nimble in responding to society's educational needs than are older, established universities. A recent national survey conducted by the American Association of Community Colleges found that two-year institutions are playing a critical role in the new technology-driven economy by narrowing the "digital divide" and delivering convenient, cost-effective computer training. ${ }^{1}$ Far from being second choice, community colleges have risen to the status of "provider of choice" for computer/technology-related education. Consequently, one might expect these institutions to provide a degree of computer training to staff equal to that training offered their customers, as technically competent employees tend to enhance both services and reputation.

Community colleges in the state of Florida are held in even greater esteem than four-year colleges or universities, and Florida residents have high expectations of their impact on the workforce. ${ }^{2}$ Several Florida two-year colleges-including Florida Community College at

Carolyn E. Poole is Director of Library Services at Chipola Junior College; e-mail: poolec@chipola.cc.fl.us. Emmett Denny is Library Services Specialist at Tallahassee Community College; e-mail: dennye@tcc.cc.fl.us. 
Jacksonville, Miami-Dade Community College, Okaloosa-Walton Community College, and Chipola Junior Collegewere ranked in the top 100 of "America's Most Wired Colleges," according to the Yahoo! 2000 list. $^{3}$ Library resources were part of the judging criteria. Florida's twenty-eight public community college libraries are well connected through an automated information system, Library Information Network for Community Colleges (LINCC), which is considered to be one of the most advanced and sophisticated networks in the country. Community college library systems in other states often look to Florida when making strategic and tactical plans for their state systems. ${ }^{4}$

If community colleges are key providers of computer/technical education, and Florida in particular is a model two-year system, one might wonder whether library employees in these statewide institutions are in a better position to deal with technochange in the workplace because they are so well supported, philosophically and practically.

\section{Review of the Literature \\ Change in the Workplace}

The nature of library work has changed dramatically in the past twenty-five years, largely because of technology. Changes are evident in role definitions, tasks, organizational structures, user expectations, vendor relations, and campus perceptions of academic library/learning resources personnel.

Larry R. Oberg's 1997 article in the Journal of Academic Librarianship on achieving clarity in an age of change reminded readers that professional librarians have yet to resolve issues of who does what in the workplace or what to call themselves. ${ }^{5}$ Traditional production work performed by librarians a generation ago is accomplished today by machines, forcing a redefinition of roles or imminent extinction. As library work as been more intellectualized, several writers have suggested that the information professional's role has expanded into that of a knowledge worker, access engineer, content expert, negotiator, trainer, facilitator, translator, teacher, and guide. ${ }^{6}$ Moreover, new titles have emerged for support staff, such as library technical assistant (LTA), library technician, and computer specialist, reflecting new directions in duties. ${ }^{7}$ Changes in roles were evident in a recent survey of position descriptions used by Association of Research Libraries (ARL) member institutions and analyzed in SPEC (Systems and Procedures Exchange Center) Kit $256 .^{8}$

\section{The mushrooming expense of buying electronic information, site licensing, and accuracy of coverage, in addition to continuous pressures to update computer hardware and software, have given rise to new worries.}

Tasks that once were the sole prerogative of librarians (e.g., reference desk shifts, cataloging, systems maintenance) have been usurped by paraprofessionals whose work, in turn, has migrated to student assistants. According to Oberg, Bonnie A. Osif, and Richard L. Harwood, task overlap exists at all levels, creating tension and resentment, devaluation of the MLS, more ambiguous work assignments, and blurring of job responsibilities. ${ }^{9}$

Editor Charles Schwartz introduced the concept of "boundary spanning" in his 1997 book, Restructuring Academic Libraries: Organizational Development in the Wake of Technological Change. ${ }^{10} \mathrm{He}$ advised libraries to realign themselves closer to campus computer networking, consortia, and scholarly communication systems to achieve better collegial integration. A trend toward flatter organizations that are less hierarchical, which is now in favor, was predicted years ago by James G. Neal. ${ }^{11}$ Libraries have slowly adopted some managerial innovations (e.g., TQM, reengineering, benchmarking) that make them more flexible and responsive to changing needs. ${ }^{12}$ Team formation and increased communication among depart- 
ments have helped emphasize the importance of everyone's contribution to successful library operations.

In her 1999 essay, "Reflections on Academic Librarianship," Karyle Butcher noted that as libraries have incorporated more electronic information resources into their collections, user demands also have accelerated..$^{13}$ The convenience of unmediated searching is assumed; yet patrons also insist on immediate personal assistance in navigating complex databases and expect instant online satisfaction from the push of a button. Customers trust that librarians are always on call to handle technicalities involved in downloading files to disks, clearing paper jams, and troubleshooting computers. The frustration voiced by Amy M. Kautzman, head of reference at Harvard's Lamont Library, is typical: "I spend more of my time solving problems brought about by technology than I do thinking up new programs for my students." 14 Soo Young Rieh's comprehensive overview of changing models of reference service highlighted empirical studies reporting library users' confusion in identifying librarians from support staff and their perplexity regarding where to go for reference consultation. ${ }^{15}$

Database interfaces and formats change (usually without announcement) at the business whims of vendors, often to the disadvantage of librarians, researchers, and scholars. The mushrooming expense of buying electronic information, site licensing, and accuracy of coverage, in addition to continuous pressures to update computer hardware and software, have given rise to new worries. Librarians are uncertain about the longevity and/or accessibility of the products they purchase today. ${ }^{16}$

In "Technological Innovation and Organization Change Revisited," Miriam A. Drake pointed out that librarian information specialists in academic environments are increasingly being tapped to manage institutional knowledge bases involving internal data, legalities of copyright, intellectual property, and consortium nego- tiations. ${ }^{17}$ They are gaining more visible roles on campus through outreach, committee participation, and faculty collaboration in the teaching/learning process. Moreover, academic librarians have entered the political arena to voice library values in the changing information marketplace.

One of the few constants in library life is change itself, so librarians may always fear falling behind in the technology race. Osif and Harwood's article on the challenges of change quotes a memorable anomaly of "running in a marathon today, clomping along in wooden shoes." ${ }^{18}$

\section{Impact of Technology on Personnel}

Opinions and anecdotes abound as to how technology has been received in libraries, although few writers have ventured beyond descriptive research to determine the impact on human resources. Some of those who have contributed survey investigations include Elizabeth $B$. Winstead, Cathleen C. Palmini, Roberta Kahan, and Dorothy E. Jones. ${ }^{19}$

Winstead examined staff and faculty reactions to automation in three libraries on a university campus during two time periods to see whether opinions changed after an integrated library system was fully implemented. ${ }^{20}$ She found insignificant differences between a survey instrument administered in 1987 and one administered in 1993. Library employees in this sample welcomed automation and expected it to enhance job satisfaction. Further, educational level had no bearing on the acceptance of automation. The majority of library personnel expressed concern about ergonomic factors associated with computer usage and suffered some negative repercussions. Automation apparently had no influence on the library's administrative hierarchy, nor did it impede interpersonal communication.

In a 1992 study of support staff in Wisconsin academic libraries, Palmini surveyed the impact of computerization and its relationship to job satisfaction. ${ }^{21}$ She hypothesized that employees who had been in their positions for an appreciable 
length of time would find it difficult to adjust to computers and would be less enthusiastic about new technology. However, such assumptions were unsubstantiated. Although the majority of this sample expressed greater job satisfaction since the introduction of automation into their libraries, they did not believe that computers offered any major timesaving benefits to their workloads. More than one-third of respondents felt that their training was inadequate, underscoring a need for better preparatory programs. Health problems and high stress levels stemming from computer usage also were prominent. Without specific reference to technology, an open-ended question asked, "What part of your job causes you the most frustration?"22 Sixty-two percent of all replies mentioned computer-related frustrations (e.g., computer being down, slow response time, not enough terminals, too many different systems to learn).

\section{After all, technostress is not terminal (although it can be caused by one).}

Kahan's 1996 interviews with nine Tennessee medical librarians revealed a strong commitment to, and an eager adaptation of, emerging computer information technology. ${ }^{23}$ Their proactive attitudes toward self-training and integrating new skills into their professional responsibilities to improve customer service were laudable, particularly in light of the inadequate institutional support that was revealed.

In an era when many academic libraries were in their initial technology acquisition phase, Jones conducted a 1988 survey of support staff perceptions in three university libraries - the University of California at Santa Barbara, Northern Illinois University in DeKalb, and the University of Richmond.$^{24}$ On the brink of a computer technology revolution, her research sought to analyze the assimilation process experienced by the bulk of library workers whose voice had yet to be acknowledged. Although Jones presented data results of a questionnaire without drawing many conclusions, the overall survey indicated a positive attitude coupled with undercurrents of personal frustration and irritation.

“Ten Years Later: Support Staff Perceptions and Opinions on Technology in the Workplace" presented the results of Jones's 1998 follow-up survey of the same sample group. ${ }^{25}$ Her initial questions, which had probed feelings about working with new technologies, training, production speed, workload demands, rewards, personnel changes, involvement in decision making, and philosophical/ social implications, were updated to also query Internet usage and health issues. Reactions to the effects of technological change generally remained positive, with slight hesitancy. The pressure to keep up had intensified, there was still a gap in training, and new health/stress anxieties over computer-related ailments surfaced. In the 1998 survey, respondents' attention shifted from automation in cataloging/ technical services to an emphasis on technological advancements in reference/research departments. Upon discovering that only 25 percent of support staff personnel were included in library technology planning and decision making, Jones argued strongly on behalf of their involvement. She observed that:

Change in the magnitude we are now experiencing is almost sure to cause turbulence. Collegial understanding among all members of a library staff, if carefully fostered, can certainly minimize trouble and maximize the many strengths available to make technological transitions smoother. ${ }^{26}$

\section{Technostress in Libraries}

Defined originally by Craig Brod in 1984, technostress is considered to be a "modern disease of adaptation caused by an inability to cope with new technologies in a healthy manner." ${ }^{27}$ This definition covers a broad range of psycho-socio-physiological problems that may be derived from the use of automation. There is an expanding 
body of interdisciplinary literature on the subject, but no definitive evidence of a technostress crisis affecting librarians ${ }^{28}$ For pertinent commentaries, the reader is referred to the following: an expert analysis by John J. Kupersmith; Gary M. Pitkin's overview of cause and reaction to stress; Virginia F. Moreland's comparison of personality types; Richard A. Hudiburg's research testing using a "Computer Hassles Scale"; Katie Clark and Sally Kalin's coping strategies; and Michael Gorman's treatise on library values. ${ }^{29}$

The 1993 World Labour Report placed computer-related jobs at the top of the list of stressful jobs, signaling that technostress has become increasingly globalized..$^{30}$ In striking contrast, the Jobs Rated Almanac continues to rank the position of librarian in its list of top twentyfive least stressful occupations, thereby reinforcing a publicly held image (yet to be challenged) that library work is not a technological field. ${ }^{31}$

During the initial phases of conversion to a statewide automation system in Ohio, Donna Popovich surveyed eighteen libraries in the early 1990s to investigate staff resistance to change, computer anxiety, and technostress. ${ }^{32}$ Attitudes toward the changes were analyzed in relation to implementation stages. She found that stress diminished as the system became fully operational and that both resistance and technoanxiety were found to be unrelated to the automation conversion.

In 1995, Pamela M. Rose, Kristin Stoklosa, and Sharon A. Gray conducted a focus group study to ascertain causes of stress among part-time reference staff in a university health sciences library. ${ }^{33}$ They determined that the increasing use of technology was partially to blame for inducing anxiety. Sources of frustration included intrusive phone calls at the reference desk while trying to serve individuals and the "technological idolatry" of students who unrealistically expected to complete class assignments using inappropriate electronic resources. ${ }^{34}$

Robin Clute's 1998 thesis examined technostress literature by evaluating fifty- eight articles for symptoms of, reasons for, and recommendations how to handle technostress. ${ }^{35}$ Coded results denoted common symptoms such as fear and anxiety, with reasons implying computer inexperience and performance anxiety. The most frequently cited recommendation to alleviate or avoid technostress was training.

One of the few traces in the literature on technostress in community college libraries and learning resource centers was a 1992 article edited by Kate D. Hickey. ${ }^{36}$ The authors contributed case study examples from Kentucky, Florida, and Georgia two-year institutions where stress resulted from rapid implementation of new technologies. Start-up of a statewide library automation system in Kentucky required employees to juggle learning new computer programs while serving increased user demands. Good planning, inclusion of staff, and thorough training were remedies for the strain.

Experiences at St. Petersburg Junior College, in Florida, showed that personnel felt overwhelmed when required to adopt and adapt to simultaneous technologies involving different operating systems. Inventory preparation for conversion to a statewide library system, while also complying with local campus networking, demanded extensive training (without equivalent practice time) that had a negative impact on public service.

At DeKalb College, in Atlanta, library staff learned to use an online catalog, email, facsimile, laser scanning, CD-ROM, and Internet technologies all at once. Surprisingly, the loss of traditional print information was the factor that created the most distress for staff.

Recommended coping strategies that were successfully employed by administrators in these community colleges included endorsement of proper balance among work/professional life, periodic breaks, participation in professional organizations, group planning to stimulate a team atmosphere, and maintaining a sense of humor. After all, technostress is not terminal (although it can be caused by one). 


\section{Purpose of the Research}

The purpose of this study was to explore the perceptions and attitudes of library personnel in Florida community colleges regarding issues of technological change affecting their work. In light of community colleges' innovative orientation, adaptability to changing educational needs, and strong state network, do Florida community college library employees react positively to change? Five general areas were scrutinized: (1) personal/philosophical factors, (2) training, (3) personnel, (4) management issues, and (5) performance, workload, and reward.

The current research was the third replication of a survey originally designed by Dorothy E. Jones of Northern Illinois University and published in Library Trends. ${ }^{37}$ Her first questionnaire and its follow-up administration ten years later revealed some reservations among university library support staff about technological change on their work. Pressures to keep up with learning new technologies in conjunction with heavier workloads and personnel decreases, were growing concerns among the support staff in the university libraries sampled. The authors of the current research were interested in seeing whether administration of the same questions to a broader spectrum of library personnel in community colleges would yield results similar to those generated from the university group.

\section{Procedures}

Permission to use her questionnaire to conduct a Florida survey was granted by author Dorothy E. Jones. The instrument consisted of thirty-four multiple-choice questions requiring one or more answers, followed by a section soliciting openended comments. Questions related to the five areas under investigation were dispersed randomly throughout the survey rather than grouped together. Personal background queries on education and experience as asked by Jones were omitted in the Florida survey so as to encourage maximum participation and anonymity. Respondents were assured the results would be tabulated and presented without reference to particular libraries.

The American Library Directory 1999$2000,52^{\text {nd }}$ edition, was used to estimate the number of workers employed in the twenty-eight Florida public community colleges..$^{38}$ Both professional and paraprofessional library staff were included in the sample population. An explanatory cover letter and a packet of surveys were mailed to the designated director of each library / learning resource center in May 2000, with a three-month window of opportunity for completion. Of the 665 surveys distributed, 302 were returned by August 2000 for a response rate of 45.4 percent.

The collected data were compiled and analyzed using descriptive statistics. Results of the research were displayed in pictorial representations as charts and graphs for presentation to the Learning Resources Commission of the Florida Association of Community Colleges at its annual convention in November 2000.

\section{Findings}

\section{Personal/Philosophical Factors}

Several questions of a subjective nature were designed to elicit personal feelings, reactions to working with computers, impact on health, stress levels, and philosophical attitudes.

Respondents were given a choice of nine words to describe their feelings about working with computers, as exhibited in table 1. Positive terms - excitement, enjoyment, pleasure, and competency-were checked most frequently. "Frustration" was the most-checked negative word. Other negative terms-inadequacy, dislike, irritation, and tolerance-were checked much less frequently. The overall picture was one of positive attitudes toward using computer technology.

Another way to probe reactions to working with changing technologies was to ask respondents how they felt about learning something new. Almost 63 percent indicated that they look forward to learning something new, compared to 12 percent who said they felt irritated because of insufficient time. 


\begin{tabular}{|lcc|}
\hline \multicolumn{3}{|c|}{$\begin{array}{c}\text { TABLE 1 } \\
\text { Descriptions of Feelings about Working } \\
\text { with Computers (N = 302) }\end{array}$} \\
\hline \hline & Frequency* & Percentage \\
\hline Enjoyment & 209 & 69.2 \\
Excitement & 189 & 62.6 \\
Competency & 155 & 51.3 \\
Pleasure & 140 & 46.4 \\
Frustration & 122 & 40.4 \\
Tolerance & 64 & 21.2 \\
Irritation & 59 & 19.5 \\
Inadequacy & 39 & 12.9 \\
Dislike & 13 & 4.3 \\
* Respondents could check as many as applicable. \\
\hline
\end{tabular}

mastering humans $(56.9 \%, \mathrm{n}=$ 302). Nearly a third thought that automation neither dehumanizes nor influences creativity.

\section{Training}

The training needs of library personnel appear to be well met in the Florida community college system. With regard to what is demanded of employees relative to learning new technologies, those who think they are expected to learn too much too fast were found to be in the minority $(24.5 \%)$.

Eighty-one percent of community college library personnel said the quality of training they receive

Although technology-related health issues (e.g., technostress, carpal tunnel syndrome, ergonomics) appear to be prominent subjects in popular literature today, they received only slight concern from this sample group of library employees. Most (51.5\%) believed that technology had made their work "neither less nor more stressful." Reasons why some felt that technology increased their levels of job stress included: too little training $(26.2 \%)$, rapid rate of change $(11.9 \%)$, things too complicated $(8 \%)$, and unrealistic pressure to produce $(9.1 \%)$. In contrast to Jones's survey reporting serious levels of medical/psychiatric technostress suffered by university library staff, it was practically a moot question in the community college ranks. People for whom technology had impacted health negatively were in the minority, and 38.9 percent had no opinion one way or another.

As for opinions on the social-philosophical implications of technology, most respondents viewed people in control of automation, rather than machines is moderately good to excellent. When asked to think beyond their own personal training experiences to judge the technology training program librarywide, the respondents' quality ratings dropped slightly to 70 percent, perceiving quality to be adequate to excellent.

As portrayed in figure 1, the question concerning whether employees are "expected to learn too many things too fast" received a significantly negative response from $62.4 \%$ of the sample.

Preferences among various types of technology education also were solicited. Workshop learning, in a structured class, and with a manual on one's own received

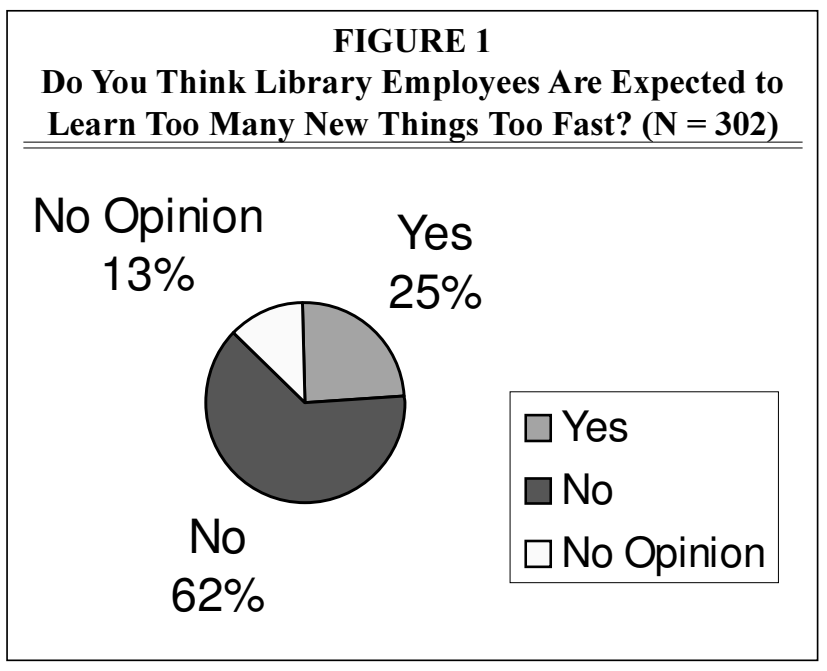




\begin{tabular}{|c|c|c|}
\hline \multicolumn{3}{|c|}{$\begin{array}{c}\text { TABLE } 2 \\
\begin{array}{c}\text { Perception of Displacement/Replacement of People } \\
\text { by Technology }\left(\mathrm{N}=281^{*}\right)\end{array}\end{array}$} \\
\hline \multicolumn{2}{|r|}{ Frequency* } & Percentage \\
\hline We have a better organization. & 88 & 31.3 \\
\hline I feel good about the changes. & 67 & 23.8 \\
\hline People have been treated fairly. & 64 & 22.8 \\
\hline We are no better off than we were before & re. 45 & 16 \\
\hline People have been treated badly. & 13 & 4.6 \\
\hline It makes me angry. & 4 & 1.4 \\
\hline & & \\
\hline
\end{tabular}

cording to 60.6 percent of respondents. Whether technology has influenced staff stability apparently was difficult for respondents to determine because nearly a third $(32.9 \%)$ of the sample had no opinion.

\section{Management Issues}

Community college

the highest number of favorable responses. Learning new technologies from a supervisor or friend were the least-preferred methods (9\%).

\section{Personnel}

Sixty-two percent of the Florida community college respondents felt that people had been neither replaced nor displaced by technology, almost twice as many as in Jones's university sample who responded more negatively. Less than two percent of the community college employees felt angry about displacement/ replacement of people by technology, and nearly a third said that "we have a better organization" as a result of it. Table 2 displays sentences that respondents chose to describe their feelings about the displacement/replacement of people by technology.

Recent patterns of personnel changes in community college libraries were difficult to deduce from this survey. Nearly a quarter $(21.5 \%)$ of the respondents indicated that there was no change in the number of library personnel in the past five years; the departments that increased or reduced employees seemed evenly divided. However, the majority $(52.5 \%)$ did not believe that technology was responsible for most of the personnel changes.

The personnel stability factor has remained about the same, ac- library personnel in Florida are positively inclined toward implementing new technologies, as evidenced by the fact that three-quarters $(75.4 \%)$ of the survey respondents rated their library's progress as being "just right" and supported quick movement into new areas. Although most were satisfied with the pace of technological development, onefourth $(25.2 \%)$ felt that new technologies were introduced into their work areas too slowly.

The availability of technical assistance was queried, with almost 81 percent rating their libraries as very good or excellent. Seventy percent of community college library/learning resource employees use the Internet in their work "a lot."

As shown in table 3, when asked what library department had made the great-

\begin{tabular}{|lcc|}
\hline \multicolumn{3}{|c|}{ TABLE 3 } \\
Greatest Positive Technological Strides \\
by Department
\end{tabular}


est positive technological advancements, Florida community college individuals ranked reference first, followed by circulation and information delivery/interlibrary loan. Only two years earlier, Jones's university study cited stronger numbers for the cataloging department as making the most progress.

Respondents were asked whether supervisors in their libraries/learning resource centers used technical surveillance to monitor staff productivity, but nearly half $(41.6 \%)$ ventured no opinion on this practice.

A low degree (37.9\%) of staff involvement in technological decision-making was revealed, although there appears to be very high interest $(72.6 \%)$ in offering more input into planning and decisionmaking regarding technology.

\section{Performance, Workload, Reward}

As revealed by their positive responses to a series of questions about technological progress in libraries/learning resource centers, community college personnel perceived that technology has made library work easier, faster, and more accurate. The majority $(63.5 \%)$ also believed that technology has increased their workload and added more responsibili- ties to their jobs. Whether technology allows more or less control over one's workday received a neutral reaction. There was little disagreement that technological advances have improved the accuracy of library records, as expressed by 82.6 percent of respondents.

Technostress resulting from too little training has apparently been alleviated in Florida by a strong statewide training program available to community college library personnel.

As displayed in figure 2, many participants felt that additional responsibilities stemming from technological changes were not adequately reflected in paychecks, job descriptions, or degree of respect from colleagues.

\section{Comparisons to Jones Study}

Library automation is new to neither universities nor community colleges, although implementation and expansion of it within these systems of higher education has varied considerably over the past few decades. In Jones's study of university support staff and the current investigation of community college personnel,

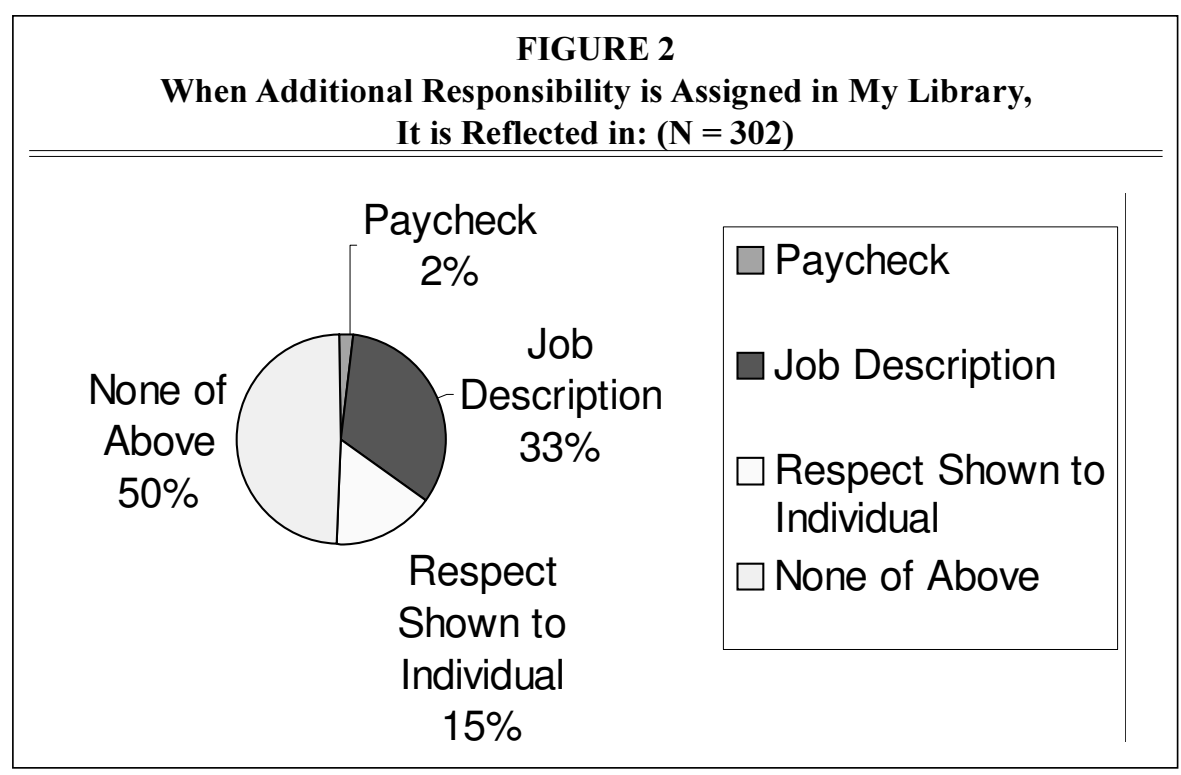


reactions to working with new technologies were quite similar. Overall, there was a positive attitude among library employees toward learning and using high-tech automation.

Both library groups of university and community college employees felt left out of decision-making during acquisition and incorporation of technology in their workplace and indicated a strong desire to participate in the process.

The impact of technology on health was surprisingly different between the university and community college respondents, with Jones's sample suffering more negative consequences. Technostress resulting from too little training has apparently been alleviated in Florida by a strong statewide training program available to community college library personnel.

There was a greater perception by Jones's university respondents of a lessstable personnel environment in libraries and the belief that people have been both replaced and displaced by technology. More community college library respondents felt that they have been treated fairly during the recent surge of technological growth than did Jones's university support staff.

\section{Implications for Planning and Implementing Technological Change}

Results of the survey imply that library personnel in Florida community colleges are receptive to a changing workplace, but greater consideration should be given to issues involving decision-making, job descriptions, and reward.

Employees feel disenfranchised from the process of incorporating new technologies into their work areas. Who better to be included in the technical planning than those who are directly affected by such changes! Increased cooperation, smoother transitions, and greater support of changes could result from such inclusion.

More attention needs to be directed toward revising and updating library job descriptions to adequately reflect increased duties involving new technologies. Rapid changes in library automation require that job descriptions at all levels be reviewed by supervisors more frequently, not just when human resource departments demand the procedure. In recent years, many Florida institutions have engaged the services of consulting firms outside education to accomplish this analysis, often to the detriment of academic library units. A compilation of current job descriptions published by ACRL offers a starting point to improve the "one-size-fits-all" industry terminology being applied by such external forces. ${ }^{39}$

Areas of performance, workload, and reward produced the most noticeable red flags.

As job descriptions are revamped in light of new technologies, it is important to be realistic about heaping more tasks on library personnel without also scaling back on inessentials. For example, community college libraries and learning resource centers in Florida have begun a "stop doing" campaign in an attempt to identify practices that are no longer viable in a changing information environment. Community colleges have a long tradition of doing more with less. Perhaps it would be better to point out that we can no longer afford to do so.

Florida public community colleges continue to receive meager increases in funding from the state legislature. ${ }^{40}$ Significant pay increases are unlikely in the near term, despite the spiraling technical complexity of library/learning resource jobs. Therefore, college administrators should think beyond traditional reward systems for their personnel and test innovative incentives and recognitions in lieu of monetary compensation. Employees with good performance records may be recognized with perks such as flextime, floating holidays, telecommuting, job sharing, career-banding (i.e., no minimum/maximum pay ranges), office space privileges, equipment upgrades, and experience certificates in the form of vouchers to attend special schools, retreats, or excursion groups. ${ }^{41}$ 
Other states may look to emulate Florida's College Center for Library Automation (CCLA) in addressing the training needs of library personnel. The wellorganized statewide series of workshops sponsored by CCLA have a proven track record of assuaging technophobias associated with learning new technologies. They are also planning to experiment with alternative training formats and will soon launch Web-based modules. Because staff training will always be a continuing need, benchmarks and best practices such as those used in Florida and other state systems should be widely disseminated to a national audience.

\section{Conclusion}

Results of the survey indicate that Florida community college library/learning resource employees are handling techochange admirably. With regard to the personal/philosophical factors investigated, they appear enthusiastic and optimistic about incorporating new technologies in their work, while manifesting nearly negligible stress-related consequences. Training needs have been covered sufficiently in Florida two-year colleges. Perceptions of the impact of technology on personnel changes are somewhat ambiguous, although most employed in community college library / learning resource centers are unruffled by any technological threat of displacement/ replacement. In terms of management issues examined, the professional mantra to include staff in planning and decisions that affect their work environments is apparently still lip service that has yet to be actualized. Areas of performance, workload, and reward produced the most noticeable red flags. Despite enhanced work performance resulting from technological progress, it also has expanded workloads while commensurate remuneration remains stagnant.

If other states are experiencing economic belt-tightening of a degree comparable to Florida, a collective national dialogue is now critical. More than merely adapting, coping, or tolerating new technology is requisite for library/learning resource specialists to take a leadership role in the information marketplace. If we fail to ride the waves of change, we may soon find ourselves drowning beneath the deluge!

\section{Recommendations for Further Research}

The authors suggest replicating this survey in Florida after a new statewide library automation system has been implemented. Although the community colleges were in final stages of migration to a new DRA system (Taos) in early 2002, the entire public higher education system is currently in a reorganizational flux. Recent government actions have decreed that the twenty-eight public community colleges and ten state universities must merge their library management systems and develop one new, common library portal. ${ }^{42}$ Under the gun to proceed immediately, they are being forced to work together cooperatively to deliver seamless library information services to a broad clientele. It is expected that the State Library of Florida-including all public libraries-and K-12 schools also will join to form an experimental future model of "womb-to-tomb" (or K-100) library services to a statewide population. As implementation of the shared system progresses, it will be interesting to compare rates of technostress among all segments of library/learning resource personnel resulting from this state-mandated technological change in the workplace.

\section{Notes}

1. Kent A. Phillippe and Michael J. Valiga, "Summary Report," Faces of the Future: A Portrait of America's Community Colleges, Apr. 2000. Available online from http:/ /www.aacc.nche.edu/ initiatives/faces/facesfut.pdf.

2. John Immerwahr and Anthony Foleno, Great Expectations: How the Public and ParentsWhite, African American and Hispanic_-View Higher Education (San Jose, Calif.: National Center for 
Public Policy and Higher Education, 2000). See also "Florida and the Nation at Large," Great Expectations: How Floridians View Higher Education, Aug. 2000, available online from http:// www.highereducation.org/reports/expectations_fl/expectations1.shtml.

3. Yahoo!, "Two-Year School Rankings," America's Most Wired Colleges 2000. Available online from http://www.zdnet.com/yil/content/college/college2000/rank_twoyears_100.html.

4. State of Florida Technology Review Workgroup, "New Developments Arising from Current Legislative Session" (Unpublished document submitted to State of Florida Legislature, Tallahassee, Mar. 2001).

5. Larry R. Oberg, "Library Support Staff Deployment and Utilization: Achieving Clarity in an Age of Change," Journal of Academic Librarianship 23, no. 1 (Jan. 1997): 42-43.

6. Allen B. Veaner, "Paradigm Lost, Paradigm Regained? A Persistent Personnel Issue in Academic Libraries," College $\mathcal{E}$ Research Libraries 55 (Sept. 1994): 389-402; Jerry D. Campbell, "Shaking the Conceptual Foundations of Reference: A Perspective," Reference Services Review 20, no. 4 (1992): 29-36; Mary Lynn Rice-Lively and J. Drew Racine, "The Role of Academic Librarians in the Era of Information Technology," Journal of Academic Librarianship 23 (1997): 37; Miriam A. Drake, "Technological Innovation and Organizational Change Revisited," Journal of Academic Librarianship 26, no. 1 (Jan. 2000): 53-59.

7. Marshall A. Berger, "Technology Brings Challenges and Opportunities for Support Staff," American Libraries (Mar. 1997): 30-31.

8. Janice Simmons-Welburn, comp., "Changing Roles of Library Professionals: SPEC Kit 256," ERIC ED 443440 (2000).

9. Oberg, "Library Support Staff in an Age of Change: Utilization, Role Definition and Status," ERIC ED 382197; Bonnie A. Osif and Richard L. Harwood, "Support Staff Issues," Library Administration \& Management 14, no. 4 (fall 2000): 228-32.

10. Charles Schwartz, ed., Restructuring Academic Libraries: Organizational Development in the Wake of Technological Change. Chicago: Association of College and Research Libraries, 1997. $74-76$

11. James G. Neal, "Academic Libraries: 2000 and Beyond," Library Journal, 121 (July 1996):

12. John Perry and Anne Woodsworth, "Innovation and Change: Can We Learn from Corporate Models? Journal of Academic Librarianship 21, no. 2 (Mar. 1995): 117-19.

13. Karyle Butcher, "Reflections on Academic Librarianship," Journal of Academic Librarianship 25, no. 5 (Sept. 1999): 350-53.

14. Amy M. Kautzman, "Digital Impact: Reality, the Web, and the Changed Business of Reference," Searcher 7 (Mar. 1999): 23.

15. Soo Young Rieh, "Changing Reference Service Environment: A Review of Perspectives from Managers, Librarians, and Users," Journal of Academic Librarianship 25, no. 3 (May 1999): $178-86$.

16. Kautzman, "Digital Impact," 18-23.

17. Drake, "Technological Innovation and Organizational Change Revisited," 53-59.

18. Osif and Harwood, "Change: Challenges and Coping, Part II," Library Administration \& Management 14, no. 1 (winter 2000): 39.

19. Elizabeth B. Winstead, "Staff Reactions to Automation," Computers in Libraries 14, no. 4 (Apr. 1994): 18-21; Cathleen C. Palmini, "The Impact of Computerization on Library Support Staff: A Study of Support Staff in Academic Libraries in Wisconsin," College \& Research Libraries 55 (Mar. 1994): 119-27; Roberta Kahan, "Attitudes of East Tennessee Medical Librarians about Evolving Computer Information Technology," Tennessee Librarian 49, no. 1 (summer 1997): 19-26; Dorothy E. Jones, "Library Support Staff and Technology: Perceptions and Opinions," Library Trends 37 (spring 1989): 432-56; — " "Ten Years Later: Support Staff Perceptions and Opinions on Technology in the Workplace," Library Trends 47 (spring 1999): 711-45.

20. Winstead, "Staff Reactions to Automation."

21. Palmini, "The Impact of Computerization on Library Support Staff."

22. Ibid., 124.

23. Kahan, "Attitudes of East Tennessee Medical Librarians."

24. Jones, "Library Support Staff and Technology."

25. $\longrightarrow$,Ten Years Later."

26. Ibid., 711 .

27. Craig Brod, Technostress: The Human Cost of the Computer Revolution (Reading, Mass.: Addison-Wesley, 1984), 16.

28. D. Fisher, "Technostress and the Librarian: A Critical Discussion," Education Libraries Journal 39, no. 2 (summer 1996): 9-14.

29. John J. Kupersmith, "Technostress and the Reference Librarian," Reference Services Review 20, no. 2 (summer 1992): 7-14, 50, available online from http://home.pacbell.net/jjkup/ tstress.html; Gary M. Pitkin, "Technostress in Libraryland," Colorado Libraries 23 (fall 1997): 58- 
61; Virginia F. Moreland, “Technostress and Personality Type," Online 17 (July 1993): 59-62; Richard A. Hudiburg, "Assessing and Managing Technostress," available online from http:// www2.una.edu/psychology/alatalk.htm; Katie Clark and Sally Kalin, "Technostressed Out? How to Cope in the Digital Age," Library Journal 121 (Aug. 1996): 30-33; Michael Gorman, "Technostress and Library Values," Library Journal 126 (Apr. 2001): 48-50.

30. James McPartin, "Ten Years of Hard Labor: Computer-related Jobs Top the List of Stressful Occupations," Information Week, 29 Mar. 1993, 52.

31. Les Krantz, Jobs Rated Almanac (New York: St. Martin's Griffin, 1999).

32. Donna Popovich, "The Effects of Computer Anxiety and Technostress, as Functions of Resistance to Change, on the Staff of the 18 Founding OhioLINK Libraries as the OhioLINK System Is Initiated," ERIC ED 401923 (1994).

33. Pamela M. Rose, Kristin Stoklosa, and Sharon A. Gray, "A Focus Group Approach to Assessing Technostress at the Reference Desk," Reference \& User Services Quarterly 37, no. 4 (summer 1998): 311-17.

34. Ibid., 314

35. Robin Clute, “Technostress: A Content Analysis," ERIC ED 423911 (1998).

36. Kate D. Hickey, ed., "Technostress in Libraries and Media Centers: Case Studies and Coping Strategies," TechTrends 37, no. 2 (1992): 17-20.

37. Jones, “Ten Years Later," 711-45.

38. American Library Directory 1999-2000, 52 ${ }^{\text {nd }}$ ed. (New Providence, N.J.: R. R. Bowker, 1999).

39. Judy Born, Sue Clayton, and Aggie Balash, comps. and eds., Community College Library Job Descriptions and Organizational Charts (Chicago: Community and Junior College Library Section, Association of College and Research Libraries, 2000).

40. Florida public community colleges were allocated $\$ 29.8$ million more state program funding in the 2001 legislative session, in comparison to a $\$ 45.4$ million increase given to the State University System, despite the fact that community colleges serve four times more students. See "2001 Session Summary of Major Legislation Passed," Florida Senate 2001 Session Summary, available online from http://www.leg.state.fl.us/publications/2001/senate/reports/summaries/pdf/ approp.pdf.

41. Kathryn Tyler, "Compensation Strategies Can Foster Lateral Moves and Growing in Place," HR Magazine 43 (Apr. 1998): 64-71.

42. State of Florida Senate Bill 1162 Second Engrossed, 8 May 2001, 47. Available online from http://www.leg.state.fl.us/session/index.cfm. 